\title{
DESIRE, RIVALRY AND COLLECTIVE VIOLENCE IN THE 'SUCCESSION NARRATIVE'
}

\author{
Hans J.L. Jensen \\ Institute of Old Testament, University of Aarhus, 8000 Aarhus C, Denmark
}

1. René Girard: A Theory of Desire, Rivalry and Collective Violence

The fundamental themes in Girard's anthropological theory ${ }^{1}$ (or 'hypothesis') ${ }^{2}$ are desire, rivalry, conflict, and solutions of conflicts by means of expulsion. According to Girard, humans are basically mimetic; the greatly increased predisposition for mimetic behaviour distinguishes humankind from all other living beings. This predisposition to mimetic behaviour and mimetic reactions-in short: mimesis-is the precondition for culture, even for language. But mimesis can destroy a culture just as easily as it can build it up. Mimetic reactions-or mimetism—running wild will make everybody the enemy

1. R. Girard, Deceit, Desire, and the Novel (trans. Y. Freccero; Baltimore: Johns Hopkins University Press, 1965); Violence and the Sacred (trans. P. Gregory; Baltimore: Johns Hopkins University Press, 1977); The Scapegoat (trans. Y. Freccero; Baltimore: Johns Hopkins University Press, 1986); Things Hidden since the Foundation of the World (trans. S. Bann and M. Metteer; London: Athlone Press, 1987); Job, the Victim of his People (trans. Y. Freccero; London: Athlone Press, 1987).

In this paper there is no room for a methodological discussion concerning the relevance of Girard's works for Old Testament exegesis in general. But condemnations ex cathedra like the one in Walter Kornfeld's presidential address to the 1980 IOSOT Congress in Vienna, 'QDS und Gottesrecht im Alten Testament' (in J.A. Emerton [ed.], Congress Volume, Vienna 1980 [VTSup, 32; Leiden: Brill, 1981], pp. 1-9), which tries to preclude any discussion by referring to the categorically sacrosant status of the sacred, are difficult to take seriously.

2. Strongly underscored in Girard, Things Hidden, pp. 437-38. 
of everybody else. Imitating another person means also to imitate the other's objects and the other's wishes; and so imitation, at least between individuals not too distant from one another, is always in danger of becoming rivalry. Therefore, culture can survive only if it possesses means to prevent 'bad mimesis', that is, conflicting desires. No culture can exist without prohibitions whose function is to channel desire in different directions in order to avoid rivalry and prevent violence.

Anger can be imitated as easily as can desire. ${ }^{3}$ A group of human beings can be hit by $\bar{a}$ general crisis against which it has no rational means of defence. In that situation everybody will become everybody else's enemy and the group will be in danger of destroying itself in general violence. But there is another possibility: a situation of rivalry between two persons can be imitated by others, and by virtue of mimesis the enemy of a single person can become a public enemy. A general crisis can be solved, or at least the group can obtain a temporary decrease in tension, by the expulsion of the common enemy, the scapegoat. According to Girard, one can imagine ritual to have originated as an artificial crisis in which prohibitions are transgressed, but where the resulting aggression is directed towards an artificial common enemy, typically a sacrificial victim. Nobody can doubt that sacrifices 'work'; it is much more difficult to explain why they do so. Girard's answer is that their very real effect is caused by their symbolized scapegoating - and scapegoating works, at least as long as it is not recognized as such.

These themes are also-such is my thesis-the themes of the socalled 'Succession Narrative'. This Old Testament literary work is a reflection-in narrative form, of course- on basic phenomena in the human world.

\section{Observations on the 'Succession Narrative'}

The Succession Narrative is generally recognized as a coherent literary work; there are some doubts about its delimitation, but normally it is defined as covering 2 Samuel 9-20 and 1 Kings $1-2 .{ }^{4}$ The designation

3. Cf. R. Schwager, Brauchen wir einen Sündenbock? (Munich: Kösel, 1979), pp. 16-17.

4. Scholars who do not want to get involved in a discussion about the redactional dimensions of the Succession Narrative normally choose this definition; so, 
Succession Narrative is the traditional one that goes back to the classical study of L. Rost; it is not at all satisfying, since the main theme in the story does not seem to be 'succession' in the strict sense; one may prefer to regard the story as a 'court history's or perhaps 'the story of King David'. ${ }^{6}$ But despite its disadvantages, 'Succession Narrative' has become a generally accepted designation for this story.

As David Gunn remarked in his book, The Story of King David, everybody seems to agree that the Succession Narrative is a work with a clear-cut tendency; however, there is not quite the same consensus on what that tendency is. ${ }^{7}$ We do not know who the author or authors of the work were and we do not know when it was written. It could be

e.g., R.N. Whybray, The Succession Narrative: A Study of II Sam. 9-20; I Kings 1 and 2 (London: SCM Press, 1968), p. 8; H. Hagan, 'Deception as Motif and Theme in 2 Sam. 9-20; 1 Kings 1-2', Bib 60 (1979), pp. 301-26; D.J.A. Clines, 'Story and Poem: The Old Testament as Literature and Scripture', Int 34 (1980), p. 120; F.E. Deist, 'David: A Man after God's Heart: An Investigation into the So-Called Succession Narrative', in W.C. van Wyk (ed.), Studies in the Succession Narrative, De Ou-Testamentiese Werkgemeenskap in Suid-Afrika (OTWSA) 27 (1984) and 28 (1985), pp. 99-129; L.G. Perdue, " "Is There Anyone Left of the House of Saul...?" Ambiguity and the Characterization of David in the Succession Narrative', JSOT 30 (1984), pp. 67-84; W. Brueggemann, David's Truth in Israel's Imagination and Memory (Philadelphia: Fortress Press, 1985), p. 41; J. Ackerman, 'Knowing Good and Evil: A Literary Analysis of the Court History in 2 Samuel 920 and 1 Kings 1-2', JBL 109 (1990). Others claim a new consensus on including 2 Samuel $2.8(12)-4.12$ (perhaps with vv. 5, 3a) in the Succession Narrative: so O. Kaiser, 'Some Observations on the Succession Narrative', in W.C. van Wyk (ed.), Studies, p. 132, with references to Schulte, Die Entstehung der Geschichtsschreibung (BZAW, 128; Berlin: de Gruyter, 1972); D.M. Gunn, The Story of King David (JSOTSup, 6; Sheffield: JSOT Press, 1978); and J. Van Seters, In Search of History (New Haven: Yale University Press, 1983).

5. E.g. Van Seters, In Search of History; J. Rosenberg, King and Kin: Political Allegory in the Hebrew Bible (Bloomington: Indiana University Press, 1986), p. 101; Ackerman, 'Knowing Good and Evil'.

6. E.g. J.W. Flanagan ('Court History or Succession Document', JBL 91 [1972], pp. 172-81) assumed an earlier stratum (without $1 \mathrm{Kgs} \mathrm{1-2}$ and the 'Solomonic' sections of 2 Sam. 9-20-the 'succession' stratum proper), which he regarded as a 'court history'. Modern interpreters normally avoid the designation 'Succession Narrative' (e.g. Gunn, Story of King David; J.P. Fokkelman, Narrative Art and Poetry in the Books of Samuel, I [Assen: Van Gorcum, 1981]; Van Seters, In Search of History).

7. Gunn, The Story of King David, p. 23; followed by Perdue, 'Is There Anyone Left?', p. 82; Brueggemann, David's Truth, p. 121. 
from the Solomonic period ${ }^{8}$ or it could be much later; ${ }^{9}$ it could be based upon historical facts, but it could also be regarded as an almost purely literary work. And this in fact is more or less the view of Gunn, ${ }^{10}$ and on this point I shall follow him. In any case, this subject is not very controversial; probably few would deny that there might be a good deal of historical information in the Succession Narrative (the problem being only how to specify it)—and nobody will deny that the Succession Narrative is primarily a literary work. ${ }^{11}$

8. According to L. Rost, Die Überlieferung von der Thronnachfolge Davids (Stuttgart: Kohlhammer, 1926); many follow him (e.g. von Rad, 'Der Anfang der Geschichtsschreibung im alten Israel' [1944], repr. in idem, Gesammelte Studien zum Alten Testaments [Munich: Chr. Kaiser Verlag, 1958], pp. 148-88; Whybray, 'Succession Narrative'-the redaction critics-and everyone else who sees in the Succession Narrative a piece of political propaganda).

9. Most radically Van Seters (In Search of History), who regards the Succession Narrative as a post-deuteronomic work.

10. On the other hand, for Rost (Die Überlieferung), as for von Rad (Anfang), there was no conflict between the Succession Narrative as a historical document and as a work of literary art. Whybray (Succession Narrative) stressed the literary side more than the historical, but ended up with a hypothesis of the Succession Narrative as a work of political propaganda (see the criticism in Gunn, Story of King David, p. 21). In order to avoid a too narrow focus on the text as historical information and/or as biased, which inevitably would bar access to the text's stylistic and thematic qualities, Gunn insisted on the text as a narrative in its own right. Gunn, however, avoided the term 'literary' and preferred 'work of art' because he wanted also to emphasize the significance of the traditions—oral or otherwise-which had functioned as the material for the present literary work (Gunn, Story of King David; on this last specific point Gunn is-from different viewpoints-criticized by Fokkelman [Narrative Art, p. 11] and Van Seters [In Search of History, p. 287]). Nevertheless, Gunn is (correctly) counted among those who, in the footsteps of Whybray, invigorated the literary investigations of the Succession Narrative (see Hagan, 'Deception', p. 301; Clines, 'Story and Poem', p. 120). A strictly literary point of view-with the resulting overestimation of the sacrosanct 'work of art'-is taken by, e.g., Fokkelman, Narrative Art. Of course, redaction criticism (Flanagan, 'Court History'; E. Würthwein, Die Erzählung von der Thronfolge Davids [Zürich: Theologischer Verlag, 1974]; F. Langlamet, 'Pour ou contre Salomon? La redaction prosalomonienne de I Rois, I-II', $R B 83$ [1976], pp. 321-79, 481-528; T. Veijola, Die Ewige Dynastie: David und die Entstehung seiner Dynastie nach der deuteronomistischen Darstellung [Helsinki: Suomalainen Tiedeakatemia, 1975]) also insists on the text's literariness - but from a totally different perspective, namely in order to stress the text's heterogeneity, not its basic homogeneity.

11. A somewhat modified 'literary approach' (in the sense that it takes the connec- 
In fact, the Succession Narrative has always been praised for its outstanding literary qualities. ${ }^{12}$ Now, since I am going to investigate some details in the Succession Narrative from the 'Girardian' point of view that I have just presented, it is perhaps interesting to mention that, according to Girard, ${ }^{13}$ the knowledge of the mimetic character of desire and the mimetic rivalry to which mimetic desire leads, is to be found not in academic philosophy or in psychology, but first and foremost in the great European literature. So in advance one is tempted to ask whether the most obvious literary part of the Old Testament may not deal with the same matters-that is, with mimetic desire, mimetic rivalry and so on.

D. Gunn proposed two major patterns in the Succession Narrative. First, 'it is possible to describe the story as one of accession, rebellion and succession. It is a story about David as king.' Secondly, the 'pattern of intrigue, sex and violence in the Bathsheba episode is played out at length in the subsequent story within David's own family' ${ }^{14}$ This is quite true. But what is the role of the story of Sheba's rebellion in 2 Samuel 20? It only fits the first of Gunn's two patterns as an instance of 'rebellion', and in this respect it is very different from Absalom's rebellion as well as from Adonijah's coup d'état; and it does not seem to have any part in Gunn's second pattern-it does not take place within David's family, and it has nothing to do with sex. ${ }^{15}$ I shall presently return to the question of the

tion between text and 'history' seriously, even if it is by stressing the text's function, not as historical report, but as interpretation) is found in Rosenberg, King and Kin.

12. Strongly emphasized by Rost (Die Überlieferung) and (with perfect justice) repeated by everybody else.

13. See e.g. R. Girard, 'To double business bound' (Baltimore: Johns Hopkins University Press, 1978), p. 89; cf. idem, A Theater of Envy: William Shakespeare (Oxford: Oxford University Press, 1991), p. 18.

14. Gunn, Story of King David, p. 89.

15. 2 Sam. 20 (vv. 2b-3 are probably redactional additions) has caused problems for exegetes. It is inevitably regarded as belonging to the sub-unit, chs. 13-20 (e.g. Flanagan, 'Court History'; C. Conroy, Absalom! Absalom! Narrative and Language in 2 Sam. 13-20 [AnBib, 81; Rome: Pontifical Biblical Institute, 1978]). S. BarEfrat (Narrative Art in the Bible [Bible and Literature Series, 17; Sheffield: Almond Press, 1989], pp. 136-37) sees a 'block of narratives' in 2 Sam. 11-20, namely a story that 'begins with David's sin of adultery with Batsheba'; but also in this narratively defined and delimited textual unity there is no real room for the Shebastory (execept for the curious coincidence that a 'daughter of Sheba' opens the unity 
actual role of sex in the overall structure of the Succession Narrative; for the moment I propose a hypothetical reformulation of Gunn's three points: the Succession Narrative is primarily about desire (rather than 'sex'), rivalry (rather than 'intrigue') and collective violence (rather than merely 'violence'). If this proposal is to any extent to the point, then it follows that a 'Girardian' point of view on the Succession Narrative should be of some interest. For these three themes are, of course, the three basic themes of Girard's work. ${ }^{16}$

\subsection{Desire and Rivalry in the Succession Narrative}

Undoubtedly, an overall concern of the Succession Narrative is the phenomenon of desire. As a matter of fact, in the episodes that deal with David and his family, we shall find nothing but desire. Andwhat is even more important-the desire is in each and every instance pictured in the shape of triangles.

a. In the story of David and Bathsheba (2 Sam. 11-12), the triangle consists of David (the subject of desire), Bathsheba (the object of desire) and Uriah (the 'obstacle', the rightful possessor of the desired object). Uriah is the obstacle for the desire of David and so desire

and a 'Sheba' closes it). But for what reason then is ch. 20 always regarded as so closely connected with the preceding chapters - if we for methodological reasons discard the hypothesis of a historical connection between Absalom's and Sheba's rebellions-except for the purely negative fact that this chapter too is not about Solomon (that is, it does not belong to the 'succession theme' stricto sensu)? Certainly there are strong similarities in style and world view between this chapter and the preceding ones; on the other hand the same thing could be said about its relations to $1 \mathrm{Kgs} 1-2$ or to $2 \mathrm{Sam}$. 3-4 (or even to $1 \mathrm{Kgs} \mathrm{12).} \mathrm{The} \mathrm{'Sheba-theme'}$ (vv. 1-2a, 14-22, which is easily extracted from the rest of the chapter as an independent literary unit) does not have closer connections to the Absalom story than to any other part of the Succession Narrative (cf. H.J. Stoebe's review of Fokkelman, Narrative Art, in $T L Z 109$ (1984), col. 108). An equally good case could probably be made for its close thematic connections with 2 Sam. 21 and 24.

16. It should be mentioned that many of the observations on the Succession Narrative in what follows are not at all 'original'; on the contrary, they can be found many times in the exegetical literature. The point is not just to make the observations but to insist on their thematic (not necessarily their literary) coherence. By doing so I shall take the consequences of some observations made in the process of research especially by Gunn (the above-mentioned characterization of the themes of the Succession Narrative), by B.O. Long ('A Darkness of Brothers: Solomon and Adonijah', JSOT 19 [1981], pp. 79-91) and by Ackerman ('Knowing God and Evil'). 
leads to rivalry and violence; David gets Uriah killed in a battle during the siege of Ammonite Rabbah.

b. In the second sequence of the Succession Narrative, the story of Amnon and Tamar, the triangle consists of Amnon (the subject of desire), Tamar (the object) and Tamar's brother Absalom. Once again desire leads to rivalry and violence. First, Amnon has to take Tamar by force, and, secondly, after a couple of years of silent resentment Absalom takes vengeance and kills Amnon.

In these two instances desire is undoubtedly sexual-so perhaps desire in the Succession Narrative is basically sexual, after all? Do we in the Succession Narrative meet a preoccupation with sex fitting our Freudian twentieth century, and does the Succession Narrative in this way suggest that behind all desire and rivalry, behind all violence and murder, sexual desire is to be found? We are for a moment tempted to ask: is sexuality the hidden reality behind everything, according to the Succession Narrative? ${ }^{17}$

The sexual desire is in these narrativies not in the least 'hidden', nor is it in any way 'suppressed'. So we are probably not in the world of Freud, at least. This impression is corroborated by the two final sequences taking place within David's family.

c. In the story of Absalom's rebellion, desire once again is triangular. Absalom is the desiring subject; kingship is the object of his desire, and the third pole of the triangle is David himself. The wish to be the king is ultimately the wish to be what David already is; so David is a perfect example of a 'model' in the 'Girardian' sense. But Absalom certainly cannot be what he desires to be without removing his own model; the model becomes the obstacle, the admirer becomes the rival. Accordingly, Absalom does everything that David did himself. Absalom establishes himself as the just judge that David is said to be in the immediately preceding chapter; ${ }^{18}$ he goes to Hebron and becomes

17. As a proposal for thematic unity in the Succession Narrative, J. Blenkinsopp ('Theme and Motif in the Succession History [2 Sam. xi 2ff] and the Yahwist Corpus', in J.A. Emerton et al. [eds.], Congress Volume, Geneva 1965 (VTSup, 15; Leiden: Brill, 1966], pp. 47-48) suggested exactly this. As we saw, Gunn is in the same line.

18. 2 Sam. 15.2-6; cf. 14.1-22. 
king there, as David did; ${ }^{19}$ with an army he goes to Jerusalem and takes the city, as David did; ${ }^{20}$ ultimately he enters David's harem and lies with his father's concubines. So far, Absalom is David's double. The conflict between Absalom and David is caused not by the differences between the two fighting parties, but by the similarities. They are identical because they want the same object and therefore act identically.

In Absalom's case, desire is precisely non-sexual; on the surface it is rather desire for power-so perhaps here the Succession Narrative has shifted from Freud to Nietzsche? The description of Absalom's desire, however, does not indicate that in Absalom there lies hidden a deep-rooted desire for power. What Absalom actually does is to imitate his father. The text does not tell us Absalom's motives for his rebellion. We could of course look for a historical explanation: Absalom as leader of a certain political faction or the like. But on the literary level of the narrative we are left to ponder. Freudians would of course make an easy case with Absalom's rebellion against his own father. ${ }^{21}$ Nietzschians would have no difficulty in ascribing a fundamental desire for power to the all-too-human subject of Absalom. ${ }^{22}$ However, the rationale of both these explanations is based on modern theories, even if they have become vulgarized to the extent that their status has shifted from theory to-more or less-unconscious ideology. Certainly, Girard's model is no less a modern theory than Freudianism and Nietzscheanism; moreover, it presents itself as a

19. 2 Sam. 15.7-12; cf. 2.1-4; Fokkelman (Narrative Art, p. 171) sees the parallel.

20. 2 Sam. 16.15; cf. 5.6-9. These verses do not belong to the Succession Narrative as a literary unity; but certainly David's capture of Jerusalem is presupposed by the Succession Narrative; see, e.g., Gunn, Story of King David, pp. 69-70; Van Seters, In Search of History, p. 285.

21. And in a way, Absalom is actually a better case than Oedipus as an antique emblem for the 'Oedipus complex'; for what Oedipus does only due to a misunderstanding, Absalom does openly.

22. To Fokkelman (Narrative Art) also there is no doubt about Absalom's motives; true to his individualistic-moralizing approach, Fokkelman has no problems in talking about Absalom's 'pride, his ambitions and his rebelliousness-in short, his ego. . . His bid for power' (p. 242); similarly, Amnon's desire is caused by his bad character: 'Amnon's act of violence reveals him as someone incapable of contact and as an uncouth egoist' (p. 108). It is the strong individualistic bias in Fokkelman's interpretation that makes it natural for him to consider the chains of events as originating in the characters' 'karma'. 
direct challenge exactly to Freudianism and Nietzscheanism. And it is no doubt true that the text does not say that Absalom's desire is 'mimetic' in the Girardian sense.

Yet, the Girardian explanation has one big advantage. Even if the text or its author does not have any conscious idea of 'mimetism' as such, the text shows the mimetism at work. And this is decisive. We do not need a pre-established idea of any ultimate reason for desire, such as infantile sexuality or a desire for power. The mere fact of Absalom's imitation is enough to explain his desire and thereby the rivalry in which he becomes involved. Therefore the Girardian model is more appropriate than any other in Absalom's case.

Since Absalom's model is a king, that is, a person invested with power, Absalom desires power. We see this fact clearly in the role that sexuality plays in the story. Sexuality is not absent from the story of Absalom's rebellion; Absalom indeed enters his father's harem. But certainly it was not sexual desire that made Absalom begin his rebellion in the first place. Absalom does not imitate his father because he wants to lie with his father's wives; he lies with his father's wives because he imitates his father. Moreover, Absalom does not enter the harem on his own initiative, but only after the advice of Ahithophel. The story of Absalom's rebellion is not 'about' sex, as the formulation of Gunn seemed to indicate, because sex is simply not important in it. The story is about mimetic desire, at least in the sense that it demonstrates the effects of mimetism. Eventually, what Absalom wants is to be David, ${ }^{23}$ if the desire to imitate the mediator grows strong enough-if the mediator is within the reach of the subject-and if the mediator accepts the challenge from the imitator, conflict will inevitably be the result.

d. In the last of the four episodes of the Succession Narrative that take place within David's family, the struggle between Adonijah and Solomon for the succession to the throne of David once again is mimetic. First, Adonijah is presented as Absalom's double. ${ }^{24}$ Adonijah is good looking - so was Absalom; Adonijah gathers a party around him-so did Absalom; Adonijah is illegally proclaimed king-as Absalom was. Solomon, for his part, is no less a double, namely of

23. This is what Girard (Deceit, Desire, p. 55) calls 'metaphysical desire'.

24. The parallels between Absalom and Adonijah are stressed, e.g., by Long, 'Darkness of Brothers', and Bar-Efrat, Narrative Art, pp. 87-88, 176. 
Adonijah; Solomon too gathers a party around him, Solomon too goes to a spring outside Jerusalem, Solomon too is proclaimed king.

Rivalry issues in violence. With his father's support, Solomon is the stronger party, and Adonijah gives up. Later, Adonijah asks Solomon for permission to marry Abishag the Shunammite. Solomon understands this wish as a hidden threat against himself - as a part of a plan of Adonijah to build himself up once again with royal prerogatives; and Solomon reacts by ordering the death of Adonijah. Once again, Adonijah and Solomon are becoming too alike; coinciding desires produce personal similarities, which rouse rivalry; only a violent solution can re-establish the hierarchy and the differences which peace presupposes.

Also in this instance, sexuality is involved. But just as in the case of Absalom, here too sexuality is not the primary factor. Solomon interprets the desire of Adonijah not as sexual, but as mimetic; Adonijah wants to resemble David as much as possible-that is, to resemble the king as much as possible, and that means also to resemble Solomon, the actual king. Adonijah wants to go on with the play of the doubles, and the result is the violent termination of mimetic rivalry.

In the first two episodes, sexual desire was the starting point. At least on the surface of it, David's desire for Bathsheba or Amnon's desire for Tamar were neither mimetic nor explained in any other way. David simply sees a very beautiful woman bathing and he desires her. This is not mimetic desire, but desire of the more basic sort, 'objective desire' (or 'physical desire', as Girard puts it), desire caused by the intuitively recognized 'value' of the object. The woman 'is' very beautiful, and so David desires her, and that's that. 'David's son Absalom had a beautiful sister named Tamar, and David's son Amnon fell in love with her'-so, what's the problem? ${ }^{25}$ Nevertheless, there is a detail in the story of Amnon that suggests a more complicated reality. After the rape, Amnon does not want Tamar any more. He 'was filled with intense revulsion; his revulsion for her was stronger than the love he had felt; he said to her, "Get up and go"'. If it had

25. In his commentary on the Song of Songs (Ruth: Das Hohelied [BKAT, 13; Neukirchen-Vluyn: Neukirchener Verlag, 1981 (1965)], pp. 73-74), G. Gerlemann compares Amnon's love for Tamar with the love scenes in the Song of Songs; cf. Blenkinsopp, 'Theme and Motif', p. 54; P.K. McCarter, Jr, 2 Samuel (AB, 9; Garden City, NY: Doubleday, 1984), and Ackerman, 'Knowing Good and Evil', p. 45. 
been the girl's beauty that roused the desire of Amnon, then why does he not want her any more? Has her beauty disappeared? Of course not. So perhaps it was not her beauty after all that made Tamar so interesting for Amnon. ${ }^{26}$ Here we seem to be in the field of what D. de Rougemont described as the love for the obstacle of love. ${ }^{27}$ And we are in the persence of what Girard has called the 'romantic lie'-

26 Amnon's sudden shift from desire to repulsion has of course puzzled the interpreters 'There is excess of love in the beginning, excess of hate at the end', says Gunn (Story of King David, p 100), according to McCarter (2 Samuel, p 324), 'A number of poets and psychologists could be cited on the readiness with which love - especially of the acute, grasping vanety-turns to hatred and the intensity of the hatred thus produced Accordingly, most commentators have thought it adequate to explain Amnon's sudden change of heart by reference to general truths of human behavior' But the simple observation that great desire turns to deep repulsion is still no explanation of why it does so To Fokkelman (Narrative Art), the text's rhetoric in itself serves as an explanation (p 107), in accordance with his whole moralizing approach, to Fokkelman there is nothing so different as hate and love 'Just as the hatred excludes the love ' ( $p$ 113)

Gurard has the one great advantage of actually offering a theoretically acceptable explanation If desire is really mimetic (that is, 'metaphysical' in the sense that the true reason for desire is the desire to be what the model is), then the object in itself is only a pretext

Even in the most favorable cases, the physical qualities of the object play only a sub-
ordinate role They can neither rouse metaphysical desire nor prolong it, moreover, the
absence of physical enjoyment does not cause the disappointment in Stendhal's and
Proust's hero when he finally possesses the object of his desire The disappointment is
entirely metaphysical The subject discovers that possession of the object has not
changed his being - the expected metamorphosis has not taken place The greater the
apparent 'virtue' of the object, the more ternble is the disappointment (Grard,
Deceit, Desire, p 88)

Amnon's desire is not mimetic, at least not on the surface of 1t, yet, the paradox is that without a mimetic foundation for his desire his hatred against Tamar seems impossible to explain I do not say that Girard's theory therefore is 'true', what I imply is that without this explanation we are left with no explanation at all, and more or less well-turned curcumlocutions like Gunn's, Fokkelman's and McCarter's can not serve as explanations. The paradox then is that even if Amnon's desire is not presented as mimetical in the text, all the surrounding texts point in no other direction, everything that belongs to the theoretical 'scenano' of Girard is present here trangles, brothers in conflict, actions that are repetitions of each other, and-as we shall see-even the all-against-one scene (that is, ultumately the scapegoatung scene)

27 D de Rougemont, Love in the Western World (trans M Belgion, New York Schocken Books, 1983), p 37 
the lie, namely, that desire is caused by the natural value of the object. ${ }^{28}$ Only Girard asks more precisely about the obstacle of love. He is not satisfied with the mere concept of the obstacle as such, but proceeds with a very concrete question: not what is the obstacle, but who is the obstacle (that is: who is the mediator, who is the one to become a rival). And it should not be too difficult to find a candidate for an obstacle, a mediator, a rival, in Amnon's own brother. Mimetic rivals or not, Amnon and Absalom are certainly an example of the 'frères ennemis', the 'enemy brothers', no less than Adonijah and Solomon ${ }^{29}$ (or Cain and Abel, Esau and Jacob, Joseph and his brothers). ${ }^{30}$ But perhaps there may be more than one obstacle in this narrative? And one can equally well make a good case of a mimetic desire also in the case of David's desire for Bathsheba. At least this possibility is hinted at by Joel Rosenberg in his King and Kin. ${ }^{31}$

\section{Girard, Deceit, Desire, pp. 2, 16, et passim.}

29. The significance of the 'mythical', 'archetypical' 'enemy brothers' motif for the Succession Narrative is stressed by Long ('A Darkness of Brothers'; cf. already Blenkinsopp, 'Theme and Motif', p. 51); Long notices that the series of violent acts 'after all, gives birth to an era of public stability (1 Kings 3-10)' (p. 89), a structure which he considers as a representation of 'a mythic pattern in the idiom of a historical narrative', the 'mythic pattern' being 'cosmos-chaos-cosmos') (p. 90), and its roots presumably going 'deeply into the ancient Near Eastern culture' (p. 91). A mythic pattern it certainly is, but it has absolutely nothing to do especially with 'ancient Near Eastern culture'; on the other hand, it has-of course-everything to do with religion (myth, ritual) as such; or, in other words, its level of abstraction belongs not to a historical, but to an anthropological discourse. So I agree deeply with Long in seeing more than mere fortuitous events in the Succession Narrative; I even agree on seeing a mythical pattern in them; but I differ from Long when it comes to the evaluation of this pattern. In itself the pattern is no explanation at all, but itself remains in need of an explanation. This explanation is - partly-given by the Succession Narrative itself, namely, in its demythologizing analysis of how conflicts come into being and how they can be solved.

30. The similarities between the Succession Narrative and the Yahwistic patriarchal narratives have been observed more than once; see, e.g., Blenkinsopp, 'Theme and Motif'; P. Gibert, Bible, mythes et récits de commencements (Paris: Editions du Seuil, 1986), pp. 118-23.

31. 'Uriah's position as one of David's gibborim [...] should cause us to modify somewhat our conventional picture of Uriah as a humble foot soldier [...]. One whose dwelling is located so near 'the king's house' is very likely an honored member of royal-military circles, one well enough known to the king's courtiers, if not to the king himself, that his naked wife seen from an adjacent rooftop would trigger astonishment of a rather precise nature' (Rosenberg, King and Kin, p. 129). 
However this may be, so far we can with some certainty conclude that the Succession Narrative is a sort of investigation into the phenomenon of desire, and that in all instances it shows how desire leads to rivalry and to violence. But do we find the second cornerstone in Girard's theory-that is, collective violence-in the Succession Narrative as well?

\subsection{Collective Violence in the Succession Narrative}

a. The rivalry between Absalom and David (in fact, David does not want any rivalry, but he is forced into it) has ended up with two armies facing each other. In the battle Absalom is isolated from his supporters, and as he rides his mule, his head is caught in the boughs of a large oak where he is left hanging between heaven and earth. Joab, David's general, drives three javelins into Absalom's chest, after which ten young men surround (סכב) Absalom and kill him. Absalom's body is flung into a large pit, and a great cairn of stones is raised over the grave.

This scenario - the image of a king, or rather a false king-hanging between heaven and earth and killed by a circle of warriors-has too many resemblances to the image of King Pentheus in Euripides' The Bacchae, and too many similarities with African sacred kings in (for example) Frazer's The Golden Bough, ${ }^{32}$ to escape the suspicion that it is more than just another factual account of 'what really happened'. ${ }^{33}$

The closest parallel to Absalom's death in the Old Testament is probably the report of the death of Achan in Joshua 7. Here too we find the great cairn of stones over the body of a victim of collective killing. And, as in the case of Achan, where 'the Lord's anger was abated', the death of Absalom really leads to a solution of the conflict. The reason for the conflict is gone and the two armies can return, reconciled and in peace. Absalom's death is a paradigmatic example of the blessings of collective violence, in which general violence is done away with by its transformation into an 'all versus one' scene,

I propose to qualify the nature of this 'astonishment' nature as mimetic desire.

32. Cf. the Old Norse myth of King Vikar's death (Gautreks Saga 7); cf. Saxo Grammaticus, Gesta danorum, VI.

33. The sacrificial connotations in the scene are also strongly underscored by Ackerman ('Knowing Good and Evil', p. 50), who compares Absalom's death with the sacrificial scene in Gen. 22; but the Biblical and theological parallel obviously hinders Ackerman from seeing that in the Absalom scene the 'sacrifice' is also demythologized-as an 'all versus one' scene. 
that is, by the elimination of one single victim.

The death of Absalom is not the only instance in the Succession Narrative where this mechanism is shown at work. Just as in the case of desire, where we found no less than four instances that showed how important this theme was for the text, so we have more examples of the same mechanism of collective violence. Repetition (or redundancy) is emphasis, as we all know.

b. In 2 Samuel 20 -the story of Sheba's rebellion-the conflict is solved in exactly the same way. Joab and his troop of soldiers, loyal to David, have pursued Sheba and his followers up to the town of Abel in the northernmost part of Israel. Joab besieges the town where Sheba has taken refuge. But then a woman among the people in the town of Abel intervenes; and she is especially qualified as a wise woman, an She proposes to hand over Sheba in order to save the rest of the town, a proposal that is immediately accepted by both the population of the town and by Joab outside. So Sheba is beheaded, his head is thrown over the wall to Joab, the enemy army disperses and the town is saved. ${ }^{34}$

c. A third example of the same mechanism is to be found in the advice that Ahithophel gives Absalom after David's flight from Jerusalem:

Ahithophel said to Absalom, 'Let me pick twelve thousand men to go in pursuit of David tonight If I overtake him when he is tred and dispirited I shall cut him off from his people and they will all scatter, I shall kill no one but the king I shall bring all the people over to you as a bride is brought to her husband It is only one man's life that you are seeking, the rest of the people will be unharmed

34 McCarter (2 Samuel, p 431) clearly sees the connection between Absalom's fate and Sheba's death

the masquerading wise woman of chap 14, who has been told by Joab what to do (14 33), persuades David to set aside the interests of the society as a whole in favor of the interest of one man, and the result is a rebellion In the present chapter the wise woman of Abel, who tells Joab what to do, counsels the sacrifice of one man in the interests of the society as a whole, and the result is the prevention of a rebellion

But by this (correct) argument, McCarter supports nolens volens the analysis here presented of these chapters no doubt the word sacrifice about Sheba's death was no more than a slip of the pen, but Obviously, of course, McCarter belongs to the great majonty of exegetes who always find it appropriate to reprimand David severely for his momentary lack of interest in 'the society as a whole' 
And Ahithophel is qualified, if not as a 'wise' man (with the root חכח), as the counsellor (יוע), whose counsel (עצה) was considered almost divine in those days. It is an interesting detail, that Ahithophel ( 2 Sam. 15.12) is described as a sacrificial priest; one may then conclude that he knows what he is talking about... This is a rather important point, in a way. For according to the Gospel of John, exactly this way of thinking was the reason for the death of Jesus:

Caiaphas, who was the high priest that year, said, 'You have no grasp of the situation at all; you do not realize that it is more to your interest that one man should die for the people, than that the whole nation should be destroyed.'

However, if there were any reminiscences of sacred violence and human sacrifice in the killing of Absalom, these connotations have completely disappeared in the killing of Sheba and in Ahithophel's wise advice. In a way, what we have here is a good example of a cultural transformation from a sacred to a non-sacred or a profane understanding of what a sacrifice is. Leave out the sacred interpretation and you have an act of 'statesmanship' left, which catches up with Machiavellianism, when it is at its best-and which, by the way, is celebrated with astonishing frequency by Old Testament scholars. Very seldom, or never, have they anything critical to say about the death of Absalom or the death of Sheba; on the other hand, almost all scholars are extremely critical of the non-violent, non-combative David whom we see in these chapters. ${ }^{35}$ We have certainly learned to master the hermeneutic of suspicion; today, it is child's play to suspect dark motives behind a

35. The height of this practically unanimous tendency among exegetes is probably reached by Fokkelman (Narrative Art), who never gets tired of telling his reader what David should have done and what he ought not to have done; he even finds it appropriate to consider David a masochist, and he sees a sado-masochistic relationship between David and Joab (e.g. pp. 263, 278). On its own premises the legitimacy of this point of view can not be denied; it is pure Nietzscheanism and as such adequate for our time. An attitude according to which one lost sheep is more important than the ninety-nine others seems to be absolutely incomprehensible to modern exegesis. David's love for Amnon and for Absalom can be decoded as weakness, as masochism. .. everything seems acceptable except one thing - love. There certainly is an 'evangelic' thematic in these chapters, and even Fokkelman cannot help making associations with the Passion narrative: 'If Joab is unsuccessful in getting another person to do his dirty work for ten pieces of silver...' (p. 245). Metaphors like this one are not only 'rhetorical'- they are indications of the common problematic in the Succession Narrative and the Passion narrative. 
seemingly pious person, and there is rarely a more comforting position than to be able to demonstrate one's lack of naive credulity towards the Biblical text... by repeating what everybody else says.

d. Two more examples with traces of an 'all versus one' scene should be noticed. The death of Uriah (2 Sam. 11) is staged as an incident so that neither David nor any Israelite can be considered guilty. Yet they all are, of course. Placing the victim between the army and the enemies and then leaving him alone by moving back looks very much like an inversion of more palpable forms of collective killing, such as stoning, pushing the victim from a cliff and the like. ${ }^{36}$ In all cases the result is the same: the victim is killed and no single member of the persecuting group has caused the victim's death. ${ }^{37}$ Similarly, the death of Amnon (2 Sam. 13) is arranged in such a way that Absalom himself is not personally guilty. He orders his servants to kill Amnon in the middle of a feast. The result is that Absalom is less guilty than if he himself had slain his brother, and the servants are less guilty than they would have been, had they performed the misdeed totally on their own initiative (cf. the Nuremberg process!). Even the scenario of the murder of Amnon has some resemblances with a scapegoating scene: everyone is assembled, the drinking is heavy, the eldest brother-and probably the crown prince-is killed. We should not identify the scene with an archaic scapegoating process (as, for example, in the story of Achan's death); what we see here is a 'de-sacralized' version of the sacrificial death. It belongs to the same thematic group as the other instances of collective killings in the Succession Narrative with the same tendencies to a 'secularization' of the killing of a single victim; but the circumstances of that killing have not totally departed from their more sacral origins.

But do we have the other extreme on the axis of collective violence in the Succession Narrative as well?-that is, an instance of collective killing or victimization, which not only looks like a ritual killing of a sacred king, as in the instance of the death of Absalom, but which

36. Equivalent forms; cf. R. Hirzel, Die Strafe der Steinigung (Abhandlungen der Philologisch-Historischen Gesellschaft der Wissenschaften, 27; 1909 [repr. Darmstadt: Wissenshaftliche Buchgesellschaft, 1967]), pp. 223-66, especially pp. 227-28.

37. Fokkelman (Narrative Art) notices the parallel between Uriah's and Absalom's death-but not that they both are 'all-against-one' scenes. 
actually is an example of the killing of a sacred king? We do not have it in the Succession Narrative proper, according to the definition that scholars normally assign to this narrative. On the other hand, we may find it in the closest possible proximity to the Succession Narrative, namely in the two narratives about David which close 2 Samuel. At this point, we shall see a 'Greek connection' appear on the horizon.

\section{Plague, Hunger-and a Greek Connection}

a. In the story about David and the plague, 2 Samuel 24 , we have a story that in many respects strangely resembles a very well known episode from a very well known Greek myth: the central episode of the myth of Oedipus, the plague over Thebes. ${ }^{38}$ In both narratives a king (David, Oedipus) commits a sin (by establishing a census, by unknowingly killing his father and marrying his mother); a public catastrophe breaks out (in both cases a plague); in both cases the king 'is guilty', and in both cases a prophet tells the king about the reason for the plague and the king willingly admits his guilt; in the Greek myth Oedipus is expelled from Thebes, whereas in the David story the death of David is avoided by establishing a sacrificial cult on the threshing-floor of Araunah; in both cases the plague disappears.

So, if we reduce the specific details of ch. 24 , we have a very traditional scheme of the sacred king; probably the king's responsibility for public disasters is a little more than a mere consequence of the concept of a sacred king. Most scholars would like to have it that way-if they mention this 'dimension' at all—but in reality it could very well be the hidden truth of sacred kingship as such. ${ }^{39}$

In connection with the death of Absalom, we observed certain parallels to the death of Achan in Joshua 7; here, in the story of David and the plague, we are once again brought back to Achan. (1) Just as Achan willingly admits his guilt, David readily accepts that he is the guilty one; (2) just as Achan was not killed alone, but with his whole family, so David here proposes not only himself as a victim, but his whole family as well:

38. Girard, Deceit, Desire; see esp. pp. 29-30.

39. Girard, Violence, pp. 103-18 et passim; Job, the Victim, pp. 86-90. 
When David saw the angel who was striking down the people, he said to the Lord, 'It is I who have sinned, I who committed the wrong; but these poor sheep, what have they done? Let your hand fall on me and on my family.'

b. This 'Oedipus pattern' probably belongs to a very widespread ideological scheme in the East-Mediterranean world-including Greece-as W. Burkert has demonstrated. ${ }^{40}$ But perhaps this 'Greek connection' could be more intimate than that. ${ }^{41}$ In the cycle of legends about Thebes to which the Oedipus myth belongs, the story of Oedipus was followed by two other stories. The one was about the 'enemy brothers', Eteocles and Polyneices, who fought for the throne of Thebes-a theme abundantly present in the Succession Narrative, especially in the concluding section about Adonijah and Solomon. But the other story was the story about Antigone. Although we do not have an 'Antigone story' in the Succession Narrative nor in its neighbourhood, we do have the very same motif of a woman guarding the body of her dead but unburied relative against the wild animals:

But Polyneices, a dishonoured corse,

(So by report the royal edict runs)

No man may bury him or make lament-

Must leave him tombless and unwept, a feast

For kites to scent afar and swoop upon (Antigone 26-30). ${ }^{42}$

Compare 2 Samuel 21:

Rizpah, daughter of Aiah took sackcloth and spread it out as a bed for herself on the rock, from the beginning of harvest until the rains came and fell from the heavens on the bodies. She kept the birds away from them by day and the wild beasts by night (v. 10). ${ }^{43}$

40. W. Burkert, 'Transformations of the Scapegoat', in idem, Structure and History in Greek Mythology and Ritual (Berkeley: University of California Press, 1979), pp. 59-77.

41. Another 'Greek connection'-from a purely literary point of view-is proposed by J. Van Seters, 'Love and Death in the Court History of David', in J.H. Marks and R.M. Good (eds.), Love and Death in the Ancient Near East: Essays in Honor of Marvin H. Pope (Guildford, CT: Four Quarters Publishing, 1987), pp. 121-24.

42. Sophocles, with an English Translation by F. Storr, I (LCL; London: Heinemann, 1981 [1912]).

43. The connection between Rizpah and Antigone has already been seen by others, e.g., by R. Kittel in his Geschichte des Volkes Israels, II (Stuttgart: Kohlhammer, 1925), p. 131. 
Certainly 2 Sam. 21.1-14 should be read 'in the context of religious primitivism'; Kapelrud was undoubtedly right in understanding the events narrated in this story in the light of a very ancient and very 'primitive' conception of sacral kingship. ${ }^{44}$

The relationship between the stories about the Saulides in 2 Samuel 21 and about David and the plague in 2 Samuel 24 and the Succession Narrative proper is assured by the choice that David has to make in ch. 24. As A. Carlson already saw in his David-The Chosen King, the choice between three years of famine, three months of flight from the enemy and three days of pestilence, is a choice between the three proverbial plagues of the prophets: sword, hunger and pestilence; and, as Carlson rightly pointed out, the 'sword' referred back to the Succession Narrative, the famine to ch. 21 , and the pestilence to ch. 24 itself. ${ }^{45}$ But this series of plagues is interesting also for another reason. For these three crises-war, famine and pestilence-are paradigmatic instances of a situation where a society will tum to sacrifice in order to re-establish the normal order - and that means: these three crises are typical for situations in which a society will turn to scapegoating. Here the sacred king-so dear to the Scandinavian schoolgains a new meaning. The sacred king became very important in such crises; and these texts in 2 Samuel confirm this impression. For the

44. A.S. Kapelrud, 'King and Fertility: A Discussion of 2 Sam. 21.1-14', in idem, God and his Friends in the Old Testament (Oslo: Universitetsforlaget, 1979), pp. 41-50. In the whole complex of 2 Sam. 21-24, W. Brueggemann ('2 Samuel 21-24: An Appendix of Deconstruction?', $C B Q 50$ [1988], pp. 383-97) prefers to see a criticism of the sacral pretensions of the Davidic dynasty. This, however, he can only achieve by neglecting the inherent rationality of 2 Sam. 21 and 24; he recognizes this by admitting that his reading is 'not necessary exegetical' (p. 386). But it is not possible to do away with the most natural reading of a text by qualifying it as reading 'innocently' and 'in the context of religious primitivism'. Moreover, in this article Brueggemann's conception of the role of kingship is much too narrow. There is, for example, no reason to discard A.R. Johnson's understanding of the צריושר 21.17 (Sacral Kingship in Ancient Israel [Cardiff: University of Wales Press, 2nd edn, 1967], pp. 1-2) by seeing it instead as an indication of the superfluity of the king - as if the role of the king in Israel consisted solely in making war. It is difficult to avoid the impression that behind Brueggemann's (and others') aversion to reading a text like 2 Sam. 21.1-14 as 'primitive', as it in fact is, lies an apologetic and ideological interest which certainly would prefer that 'les israélites ne sont pas comme les autres'.

45. A. Carlson, David, the Chosen King (Stockholm: Almqvist \& Wiksell, 1964), pp. 197, 212. 
pestilence is done away with by King David's victimization of himself; ${ }^{46}$ the famine is done away with by killing seven of Saul's sons and grandsons; and the war between Absalom and David is ended by the death of Absalom, the king's son, the false king - a death worthy of an African sacral king, and a death like the death of the sons and grandsons of a former king, and a false king: Saul.

\section{Conclusion}

Regardless of the opinion one may have on the literary unity of the Succession Narrative, it is a thematic unity-not in the sense of being totally without internal inconsistencies and so forth, but in the more significant sense of dealing with the same subject or the same circle of subjects, which are: desire (objective and mimetic), rivalry, collective violence and scapegoating. Redundance is insistence: the narrative repeats itself with variations; over and over again desire leads to rivalry and rivalry leads to violence-collective violence against a single person. Accordingly, the theme of the narrative is not only these subthemes but rather their connection. In this way, the Succession Narrative is an anticipation of the Girardian anthropology, or, if you prefer, a contribution to the investigation of the relationship between mimetism, desire, rivalry and violence. And as such, besides being a work of art, the Succession Narrative performs a kind of 'phenomenological'

46. In David's speeches in 2 Sam. 24.10, 17, Brueggemann ('2 Samuel 21-24', p. 393) sees 'a staggering theological confession' and a 'dramatic move' which 'is stunningly beyond our expectations. . David here has forsaken that mode of royal pretension and now speaks as a child of the covenant.' Brueggemann's view seems to presuppose that the disasters in the Succession Narrative and in 2 Sam. 21 and 24 were due to David's overestimation of sacral kingship. This is not the fact; the Bathsheba accident and Amnon's death had nothing to do with sacral kingship. More important, however, is that David's confession is not against the ideology of sacral kingship, but totally in conformity with it. What David is doing here is exactly what he, as a sacral king, was supposed to do-namely, to take the responsibility for a public disaster against which no rational means existed. This point is proved by the basic structural identity with the Oedipus myth. Here, Brueggemann's (and many others') fundamental error is not to allow for the negative (one may say 'dark other') side of sacral kingship. Surely 2 Sam. 24 is not an instance of 'primitivism' pure and simple - this is assured by the fact that the events are seen through the eyes of David, the king; but the basic logic of the events, be they in accordance with the 'covenant', as Brueggemann puts it, or not, has not changed. 
investigation in the realm of human behaviour and reactions. The indisputable 'literary' or 'artistic' qualities of a text should not exclude the possibility that it could possess also real insights into human phenomena-not in spite of, but because of these same qualities.

Is it then by mere coincidence that what is probably the most outstanding example in the Old Testament of a text which deals with the thematic complex of desire, mimetism, nvalry and collective killingso impressively investigated by Girard the teacher of literature-also happens to be what is, according to a widespread scholarly consensus, the most 'literary' text in the whole Old Testament?

\section{ABSTRACT}

Rene Gurard's 'mımetıc theory' outlınes a theoretıcal model accordıng to which mimetism creates desire, desire creates nvalry, and rivalry creates a general crisis which may be solved by an 'all-aganst-one' action (scapegoatıng) To a large extent, this model is based on literary examples, since literature, much more than philosophy or psychology, has been aware of the force of mimetism The so-called 'Succession Narrative' is no doubt one of the most 'literary' sections in the Old Testament It may also be read as a reflection on the same themes as those of Grard's theory-a reflection that seems to base itself on the same sequental order

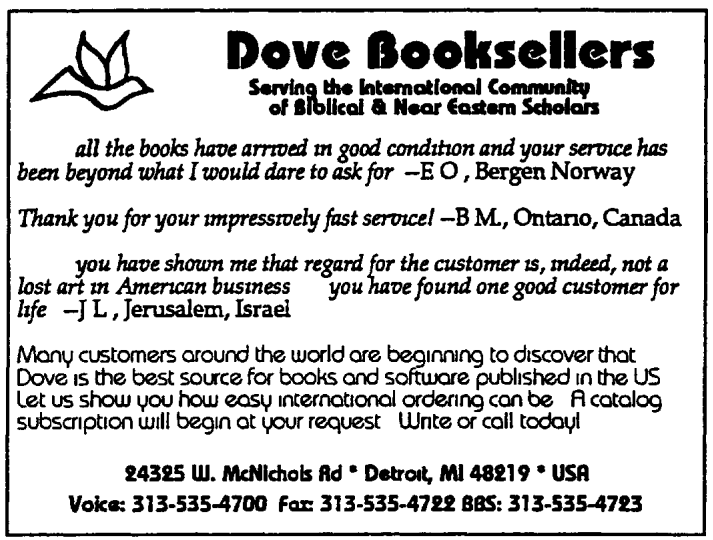




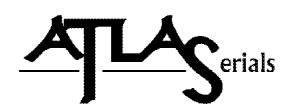

Copyright and Use:

As an ATLAS user, you may print, download, or send articles for individual use according to fair use as defined by U.S. and international copyright law and as otherwise authorized under your respective ATLAS subscriber agreement.

No content may be copied or emailed to multiple sites or publicly posted without the copyright holder(s)' express written permission. Any use, decompiling, reproduction, or distribution of this journal in excess of fair use provisions may be a violation of copyright law.

This journal is made available to you through the ATLAS collection with permission from the copyright holder(s). The copyright holder for an entire issue of a journal typically is the journal owner, who also may own the copyright in each article. However, for certain articles, the author of the article may maintain the copyright in the article. Please contact the copyright holder(s) to request permission to use an article or specific work for any use not covered by the fair use provisions of the copyright laws or covered by your respective ATLAS subscriber agreement. For information regarding the copyright holder(s), please refer to the copyright information in the journal, if available, or contact ATLA to request contact information for the copyright holder(s).

About ATLAS:

The ATLA Serials (ATLAS $®)$ collection contains electronic versions of previously published religion and theology journals reproduced with permission. The ATLAS collection is owned and managed by the American Theological Library Association (ATLA) and received initial funding from Lilly Endowment Inc.

The design and final form of this electronic document is the property of the American Theological Library Association. 